Vol. 13 (2004): 378-389.

\title{
Appropriate classification of three Swedish soils for agrarian and environmental management
}

\author{
Lena Slånberg \\ Swedish University of Agricultural Sciences, Department of Soil Sciences, PO Box 7014, SE-750 07 Uppsala, \\ Sweden,e-mail: lena.slanberg@mv.slu.se \\ Lars D. Hylander \\ Uppsala University, Department of Earth Sciences, Air \& Water Science, Villavägen 16, SE-752 36 Uppsala, \\ Sweden, e-mail: lars.hylander@hyd.uu.se
}

\begin{abstract}
Classification of soils according to internationally agreed criteria forms a valuable base for scientific and political analyses. The objectives of this study were to evaluate two soil classification systems and relate them to agricultural and environmental concerns, principally phosphorus leakage, by classifying three Swedish, arable soils. The Bjärröd soil was classified as a Rupti-Endogleyic Phaeozem according to the World Reference Base for Soil Resources and as a coarse-loamy, mesic Oxiaquic Hapludoll according to the Soil Taxonomy. Bjelkesta was classified as an Orthieutric Gleysol and a fine, frigid, Typic Endoaquept, respectively, and Götala as a Haplic Arenosol and a frigid Typic Udipsamment. We evaluated some changes to the classification systems proposed by Nordic scientists and found the classification of Bjärröd misleading and suggest it being classified as a Cambisol/Inceptisol and that information of the characteristically high base saturation in Bjelkesta and the spodic character in Götala being included in their names. This information is useful for decisions regarding agrarian and environmental management of the soils.
\end{abstract}

Key words: nutrient leakage, phosphorus sorption, soil classification, Soil Taxonomy, World Reference Base for Soil Resources

\section{Introduction}

The European Parliament decided in 2002 to give soil quality the same status as water and air in order to protect the soils from further degradation and to safeguard the fertility and agronomic value of agricultural land (Commission of the European Communities 2002, p. 8). Soil classification is a valuable tool for rational decision making about appropriate usage of soils. Several national and international soil classification systems have been developed. Lately large efforts have been spent to form an international soil classification system within the frame of the Food and Agriculture Organization of the United Nations (FAO), the International Union of Soil Sciences (IUSS) and the International Soil Reference and Information Cen- 
Vol. 13 (2004): 378-389.

tre (ISRIC). The World Reference Base for Soil Resources (WRB) system was initiated in 1990 and supposed to replace the existing FAO system (FAO 1998). Efforts are also done to adapt the system of the USA, Soil Taxonomy, for global use (Soil Survey Staff 1998).

Nordic soil scientists have proposed changes to WRB in order to further improve its credibility (Tiberg et al. 1998, Kirchmann et al. 1999, Krogh and Greve 1999, Greve et al. 2000). Proposed changes regarding classification of cultivated soils and podzolized soils are of special concern for many Swedish soils. When classifying cultivated soils, the topsoil characteristics, including those easily altered through short-term farming practices, will change the classification at the highest level, in spite of the initial intention that the classification shall not be influenced by short-term management. In many cases, farming practices, such as ploughing and liming, results in A-horizons/epipedons deep enough and with enough high base saturation to result in classification as mollic or umbric. Thereby, Phaeozems/Mollisols of anthropogenic origin are very common in long-time cultivated soils in large parts of north-western $\mathrm{Eu}-$ rope, including Sweden (Kirchmann et al. 1999, Krogh and Greve 1999), in spite of the intention to reserve these soil groups for grassland soils (Soil Survey Staff 1974). See Krogh and Greve (1999) for further discussion of man-made mollic and umbric horizons.

Soils considered typical Podzols in the Nordic countries according to tradition and sometimes also according to Soil Taxonomy, often fail to meet the colour criteria of the WRB spodic horizon. In addition, $\mathrm{pH}$ values higher than the limit for spodic horizons due to liming, often exclude arable soils otherwise having spodic characters (Greve et al. 2000). As a result, Spodosols were found in forested sites only, when 29 soils in southern Finland were classified according to Soil Taxonomy. Many podzolized, cultivated soils were found, but they could not be classified as Spodosols owing to the lack of evidence of accumulation of $\mathrm{Al}$ and $\mathrm{Fe}$, because the upper horizons had been mixed by deep ploughing (Yli-Halla and Mokma 1999). The laboratory method used to measure the amount of amorphous aluminium $\left(\mathrm{Al}_{\mathrm{ox}}\right)$ and iron $\left(\mathrm{Fe}_{\mathrm{ox}}\right)$, used as one criterion for the spodic horizon, is the same as is used to estimate the phosphorus (P) sorption capacity of a soil. This means that the presence of a spodic horizon also can be used as an indicator for soils with a larger $\mathrm{P}$ sorption capacity than comparable non-spodic, often coarse textured, soils. The larger the content of $\mathrm{Al}_{\mathrm{ox}}$ and $\mathrm{Fe}_{\mathrm{ox}}$ and the thicker the spodic layer is, the higher will the $\mathrm{P}$ sorption capacity be. Knowledge about P sorption capacity and P-saturation, often defined as the molar ratio of $\mathrm{P}$ to $\mathrm{Al}$ and $\mathrm{Fe}$ contents extracted by ammonium oxalate, $\mathrm{P}_{\mathrm{ox}} / \alpha\left(\mathrm{Al}_{\mathrm{ox}}+\mathrm{Fe}_{\mathrm{ox}}\right)$ (Campillo et al. 1999), is important in order to adjust agricultural practices so that $\mathrm{P}$ losses from soils and eutrophication of waters are reduced.

The aim of this study was to analyse and describe three soils from the agricultural experiment fields at Bjärröd, Bjelkesta, and Götala in the south and central Sweden, in order to identify their dominating properties from an agricultural and environmental point of view and to classify them according to the WRB (FAO 1998) and Soil Taxonomy (Soil Survey Staff 1998) soil classification systems. We also analyse the outcome of the classifications and discuss if the proposed changes to WRB would influence the classification of the studied soils. In such case, we evaluated if the differences were increasing the usefulness and understanding of the agricultural and environmental properties, principally the P leakage, of the soils. Finally, we propose some further changes to the classification systems.

\section{Sites - background, land use, and climate}

\section{Landscape and geology}

The site at Bjärröd $\left(55^{\circ} 42^{\prime} \mathrm{N}, 13^{\circ} 43^{\prime} \mathrm{E}\right.$, alt. $105 \mathrm{~m}$ above sea level) is located in Scania, $1 \mathrm{~km}$ to the south of Bjärsjölagård, southern Sweden. The site is located $14 \mathrm{~m}$ to the north and $18 \mathrm{~m}$ to the east of 
Slånberg, L. \& Hylander, L.D. Classification of three Swedish soils

the north-western corner of the field experiment R3-0059 of the Swedish University of Agricultural Sciences (SLU). Bjärröd is situated on the central Scanian shale and primary rocks till, which covers Phanerozoic sedimentary and magmatic rocks of the Baltic Shield (Clason and Granström 1992, Fredén 1995). During some time, calcaric material was deposited (see horizon $2 \mathrm{Cg}$ ), possibly of local origin from the calcaric bedrock, later covered by shale and primary rock till transported there by the ice. The soil is representative of the less fertile soils in the transition areas between fertile arable soils in the southwest and forests further to the north in the county of Scania. The site has been subsurface drained during the latest century. The surrounding topography is gently undulating, and the test pit is located at the lower part of a more than $500 \mathrm{~m}$ long slope, without any micro relief.

The site at Bjelkesta $\left(59^{\circ} 43^{\prime} \mathrm{N}, 17^{\circ} 24^{\prime} \mathrm{E}\right.$, alt. 8 $\mathrm{m}$ above sea level) is located in Uppland, within 1 $\mathrm{km}$ from a bay of lake Mälaren in centre-eastern Sweden. The site is located $6 \mathrm{~m}$ east of the eastern end and $8 \mathrm{~m}$ south of the north-eastern corner of the SLU field experiment R3-3038, No 6/83. Bjelkesta is situated on granitoid bedrock in the Svecokarelian Province of the Baltic Shield (Fredén 1995). The soil is representative of the arable clay soils of the plain districts of Svealand, formed by sedimentation of glacial clay during and after the withdrawal of the ice of the Weichselian glacial age. The soil material is originating from calcaric bedrock in the Baltic Sea, outside Gävle (Clason and Granström 1992). The site has been subsurface drained during the latest century. The field is almost flat and the surrounding topography is gently undulating with bedrock frequently cropping out. The test pit is located in the centre of a more than $2 \mathrm{~km}$ long slope towards the shore, without any micro relief.

The site at Götala $\left(58^{\circ} 22^{\prime} \mathrm{N}, 13^{\circ} 29^{\prime} \mathrm{E}\right.$, alt. $121 \mathrm{~m}$ above sea level) is located in Västergötland, Sweden, $2 \mathrm{~km}$ to the east of Skara on the Skara plain. The site is located $5 \mathrm{~m}$ south of the southern end and $7 \mathrm{~m}$ east of the south-western corner of the SLU field experiment R3-3038, No 304/82. Götala is situated in the southwest Scandinavian Province, on the Eastern Gneiss Segment of the Baltic
Shield (Fredén 1995). Its large portion of sand and silt is a result of deposition close to the mouths of the rivers during withdrawal of the glacial ice. The soil has lower clay content than generally encountered in the plain districts of northern Götaland (Clason and Granström 1992). It is formed in the transition area between clayey soils to the west and sandy soils covered with forests further east, on the western shore of lake Vättern. The area is almost plain and the site was subsurface drained 1937. The surrounding topography is almost plain. The test pit is located in the centre of a more than $2 \mathrm{~km}$ long very gentle slope towards northwest, without any micro relief.

\section{Land use}

At Bjärröd, annual field cropping with cereals, oil crops, potatoes and sugar beets, with annual ploughing, is dominating the area. The region has a large livestock of primarily cattle and sheep and about $40 \%$ of the fields are grown with ley. The site at Bjärröd has been in cultivation for about 4000 years (Weibull 1923). Until the 1940s, the site was in a typical farm production for the area, with cereals, legumes, potatoes, sugar beets and leys for dairy production. In the early 1940s, the production was changed to an extensive sheep production. Only limited amounts of mineral fertilizers were used during the era of dairy production and, since 1942, no mineral fertilizers nor chemical pesticides or herbicides have been used at the site (Gesslein 1995). Most of the farm was in perennial leys when the experiments started, and there is still perennial ley at the place of sampling. Since only limited amounts of farmyard manure had been applied to the soil, and the soil does not generate larger amounts of nutrients by weathering, it was very poor in nutrients when the field experiments started in 1979. At that time, soil reserves of easily soluble $\mathrm{P}$ and $\mathrm{K}$ were 10 and $66 \mathrm{mg} \mathrm{kg}^{-1}$ airdry soil, respectively, measured with the AL-method (Egnér et al. 1960). Accordingly the soil qualified for the lowest class of five classes for P and the second lowest for K. See Eriksson et al. (1997) for the concentration criteria for the P- and K-AL 
Vol. 13 (2004): 378-389.

classifications. The $\mathrm{pH}\left(\mathrm{H}_{2} \mathrm{O}\right)$ was 5.7 in the plough layer and higher in the subsoil, where also P-AL was somewhat higher (Gesslein 1995). In SLU experiment No R3-0058, six different organic and conventional agricultural systems are compared concerning effects on soil nutrient and biological status. SLU No R3-0059 is a fertilization experiment with different levels of N, P, K, and lime.

The site at Bjelkesta has been above sea level less than 1000 years. Annual field cropping with cereals and annual ploughing dominates the region. Until the 1950s, the site was in a typical farm production for the area with cereals, legumes and leys for dairy production. In the early 1950s, the dairy production was abandoned, the leys were replaced by cereals and fields in fallow land one year and with oil crops the following year were included in the rotation until the mid 1970s. Presently winter wheat makes up half of the crop rotation and barley, oats and peas the other half (Rudolphsson 2000, personal communication). The site is situated close to the farm centre and has historically received large amounts of animal manure. This has resulted in large soil reserves of $\mathrm{P}$, which has been further increased with mineral fertilizers. The site is also fertilized with $\mathrm{N}$ and $\mathrm{S}$. Weathering from illitic clay minerals supplies the crops with $\mathrm{K}$. The concentrations of AL-extractable $\mathrm{P}$ and $\mathrm{K}$ were 212 and $454 \mathrm{mg} \mathrm{kg}^{-1}$ air-dry soil, respectively, in 1998 (Swedish University of Agricultural Sciences 1999). Accordingly, the soil contained more than average for Swedish soils of $\mathrm{P}$ and $\mathrm{K}$ and was placed in the highest $\mathrm{P}$ - and $\mathrm{K}-\mathrm{AL}$ classes. The $\mathrm{pH}\left(\mathrm{H}_{2} \mathrm{O}\right)$ was 7.2 in the plough layer and higher in the subsoil, due to lime in the parent material, transported by the glacial ice from the northeast. The high soil P content and its plant availability are studied in SLU field experiment R3-3038 since the early 1980s at Bjelkesta, Götala, and four other sites.

The site at Götala has been in cultivation at least since the thirteenth century. Main crops grown in the region are cereals, leys and potatoes with annual ploughing, and there are also pasturelands and mixed forests. The site is in a typical farm production for the area with cereals, potatoes, and leys for dairy production. The site is situated close to the centre of an experimental farm and has received large amounts of animal manure until the experiment started in 1982, which have resulted in large soil reserves of P (Bengtsson 2000, personal communication). The site is now fertilized with $\mathrm{N}$ only. The concentrations of AL-extractable P and $\mathrm{K}$ were 286 and $230 \mathrm{mg} \mathrm{kg}^{-1}$ air-dry soil, respectively, in 1998, which correspond to P-AL class V and K-AL class IV (Swedish University of Agricultural Sciences 1999). The $\mathrm{pH}\left(\mathrm{H}_{2} \mathrm{O}\right)$ was 6.3 and is maintained by using calcium nitrate as $\mathrm{N}$ fertilizer.

\section{Climate}

Mean annual air temperature at Bjärsjölagård (1 $\mathrm{km}$ from Bjärröd) is $7.3^{\circ} \mathrm{C}$ over a 19 -year period, $5.7^{\circ} \mathrm{C}$ at Uppsala $\left(25 \mathrm{~km}\right.$ from Bjelkesta) and $5.9^{\circ} \mathrm{C}$ at Skara (2 km from Götala) over a 30 -year period (Fig. 1). Mean annual soil temperatures at $0.5 \mathrm{~m}$ depth were estimated by adding $1^{\circ} \mathrm{C}$ to the mean annual air temperatures (USDA, Soil Conservation Service 1981). There is a difference of more than $6^{\circ} \mathrm{C}$ between mean winter and mean summer temperatures at all sites (Alexandersson et al. 1991). The soil temperature regime is mesic at Bjärröd and frigid at Bjelkesta and Götala (Soil Survey Staff 1998). Mean annual precipitation is $764 \mathrm{~mm}$ at Bjärröd over a 19-year period, $544 \mathrm{~mm}$ at Uppsala (Bjelkesta) and $556 \mathrm{~mm}$ at Skara (Götala) over a 30 -year period (Fig. 1). In most years, none of the soils are dry in any part of the control section for as long as 90 consecutive days. The soil is on average covered by snow for about 50 days per year at Bjärröd and for 75-100 days per year at Bjelkesta and Götala (Raab and Vedin 1995). The soil moisture regime is defined as udic at all three sites (Soil Survey Staff 1998).

\section{Soil profile description}

\section{Bjärröd profile}

The effective soil depth is moderately deep. The last root channel ends at $95 \mathrm{~cm}$. There are no rock outcrops and very few coarse gravel and stones left 


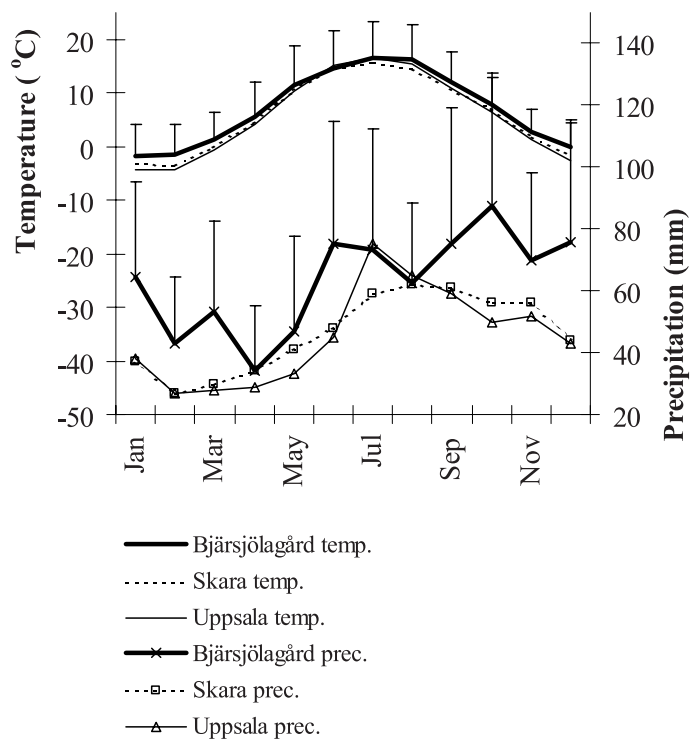

Fig. 1. Mean monthly precipitation and temperature 1980-1998 at Bjärsjölagård, 1 km to the north of the Bjärröd sampling site (bars indicate $1 \mathrm{SD}$; registration lists at Malmöhus läns hushållningssällskap, Malmö, Sweden) and 1961-1990 at Skara, 2 km west of Götala, and at Uppsala, about $25 \mathrm{~km}$ north-east of Bjelkesta (Alexandersson et al. 1991).

in the field, but stone fences around the field are constructed by $20-40 \mathrm{~cm}$ large, subrounded stones, consisting of diabase, strongly weathered granite and some limestone. There were no sign of erosion and no observable surface cracks at the sampling time, which may depend on the wet conditions. The soil was moist to $95 \mathrm{~cm}$ below the surface and wet below that depth. The groundwater table (fresh water) was deep and was encountered at $125 \mathrm{~cm}$ depth. The soil is non-calcareous to a depth of $1 \mathrm{~m}$, below which it is strongly calcareous.

\section{Bjelkesta profile}

The effective soil depth is moderately deep. Maximum root depth is $60 \mathrm{~cm}$. There are no rock outcrops and very few to few coarse gravel of granite. No erosion or cracks were observed at the sampling time. Up to one meter deep cracks are formed in dry summers (Rudolphsson 2000, personal communication). The soil was moist to $70 \mathrm{~cm}$ below the surface and wet below that depth. The groundwater table (fresh water) was moderately deep and was encountered at $85 \mathrm{~cm}$ depth. The soil is noncalcareous to a depth of $55 \mathrm{~cm}$, below which it is moderately calcareous.

\section{Götala profile}

The effective soil depth is moderately deep. Maximum root depth is $60 \mathrm{~cm}$. There are no rock outcrops and very little coarse gravel of gneiss, granite and clay slate. There was no sign of erosion and no observable surface cracks at the sampling time. The soil was moist to $90 \mathrm{~cm}$ below the surface and wet below that depth. The soil is excessively drained by nature. The groundwater table (fresh water) was deep and was encountered at $110 \mathrm{~cm}$ depth. The soil is also non-calcareous to that depth.

\section{Methods}

The particle size analysis was performed using sieving and the pipette sedimentation procedure (Ljung 1987). The texture was estimated by hand below $0.60 \mathrm{~m}$ in Bjärröd and below Ap at Bjelkesta and Götala. Soil $\mathrm{pH}$ was determined potentiometrically in water at a 1:5 volume ratio. Plant available $\mathrm{K}, \mathrm{P}$, and $\mathrm{Mg}$ in soil were estimated by extraction with the AL-method (0.1 M ammonium lactate, $0.4 \mathrm{M}$ acetic acid, pH 3.75) (Egnér et al. 1960). Soil $\mathrm{N}$ and organic $\mathrm{C}\left(\mathrm{C}_{\mathrm{o}}\right)$ were determined by combustion (LECO 1994). 0.1 M ammonium oxalate ( $\mathrm{pH} 3$ ) was used for the extraction of amorphous $\mathrm{Al}\left(\mathrm{Al}_{\mathrm{ox}}\right)$ and $\mathrm{Fe}\left(\mathrm{Fe}_{\mathrm{ox}}\right)$ according to Buurman et al. (1996), but without the 'superfloc' flocking agent. Phosphorus $\left(\mathrm{P}_{\mathrm{ox}}\right)$ was determined in the same extracts. Cation exchange capacity (CEC) was determined after saturation with $1 \mathrm{M}$ sodium acetate $(\mathrm{pH} 8.2)$, and the Na-saturated samples were treated as for exchangeable base-cations as described below and analysed for $\mathrm{Na}$. The amounts of exchangeable $\mathrm{Ca}, \mathrm{K}, \mathrm{Mg}$, and $\mathrm{Na}$ were determined after replacement by $1 \mathrm{M}$ ammonium acetate (pH 7) (United States Salinity Laboratory Staff 
Vol. 13 (2004): 378-389.

1954). The same amounts of $\mathrm{Ca}, \mathrm{K}, \mathrm{Mg}$, and $\mathrm{Na}$ are assumed to be extracted with the ammonium acetate at $\mathrm{pH} 7$ as was displaced by sodium acetate at $\mathrm{pH}$ 8.2. All elements were determined by ICPAES (Perkin-Elmer 1993). For samples with 100\% base saturation, exchangeable $\mathrm{Ca}$ was calculated as the difference $\mathrm{CEC}-(\mathrm{K}+\mathrm{Mg}+\mathrm{Na})$, because extractable $\mathrm{Ca}$ in these soils originates from both exchangeable $\mathrm{Ca}$ and dissolved $\mathrm{Ca}$ minerals. In the classifications it was assumed that the soils contain high activity clays (CEC $\geq 24 \mathrm{cmol}_{\mathrm{c}} \mathrm{kg}^{-1}$ clay) and that carbonates are of primary origin. We did not analyse for citric acid extractable $\mathrm{P}$, but we assumed it was $\leq 250 \mathrm{mg} \mathrm{P}_{2} \mathrm{O}_{5} \mathrm{~kg}^{-1}$ in the Bjärröd Ap-horizon because of the low P-AL and Olsen-P, and because the crops indicated $\mathrm{P}$ deficiency.

The profile investigations were made on plots nearby the field experiments. At Bjärröd, the soil was never mineral fertilized, and at Bjelkesta and Götala, $\mathrm{N}$ and $\mathrm{K}$ have been added in amounts normal for the areas. The soil profile descriptions were made according to "Guidelines for Soil Descriptions' (FAO 1990). Colour determinations were made using the 'Munsell Color Charts' (Munsell soil color charts 1975). The observations together with the textural analysis are presented in Table 1.

\section{Results and discussion}

\section{Diagnostic properties, classification and application to land-management}

\section{Bjärröd profile}

The plough layer fulfils the requirements for a mollic A-horizon/epipedon. In the subsoil, colour and structure indicate the presence of a cambic horizon. Differences in carbonate and clay contents within the subsoil are assumed to be due to lithologic discontinuities. Below $0.75 \mathrm{~m}$ in the $2 \mathrm{Bg}$ and $\mathrm{Cg}$ horizons, rusty mottling on ped faces and along root channels and an olive grey colour (Table 1) inside the peds indicate a fluctuating ground water regime. The soil did not show any colour reaction when using potassium ferric cyanide solution, which would indicate reducing conditions, but we still consider it has gleyic properties because the colour pattern is indicating periodical influence of a high ground water table. The soil classification according to WRB: Rupti-Endogleyic Phaeozem. Alternatively, if the gleyic properties cannot be justified, it will key out as a Ruptic Phaeozem. According to Soil Taxonomy the soil is a coarseloamy, mesic Oxyaquic Hapludoll.

There have been many objections against so many Nordic soils being classified as Phaeozems/ Mollisols, as these groups were initially intended for steppe soils with naturally deep, dark A-horizons/epipedons. In Denmark, $45 \%$ of the arable soils have mollic horizons, and almost $25 \%$ are classified as Phaeozems according to the WRB (Krogh and Greve 1999). In Sweden, fewer arable soils have been classified, but of those classified, some are classified as Phaeozems/Mollisols (Kirchmann and Eriksson 1993, Kirchmann et al. 1996, 1999). Kirchmann et al. (1999) propose a higher $\mathrm{C}_{\mathrm{o}}$ limit than the present $0.6 \%$ for mollic horizons formed in a cool climate to exclude some soils from the Phaeozem/Mollisol group. In the traditional Swedish soil classification (Ekström 1953) the lower limit for "humus rich" mineral soil is $3.5 \% \mathrm{C}_{\mathrm{o}}$, which might be useful as a limit for a mollic horizon in WRB and Soil Taxonomy too. As a comparison, the median value of $\mathrm{C}_{\mathrm{o}}$ content in agricultural mineral soils in Sweden is $2.3 \%$, or a little higher than in the Bjärröd soil. Approximately $13 \%$ of the Swedish agricultural mineral soils have $\geq 3.5 \% \mathrm{C}_{0}$. These soils are mainly encountered in the wooded districts of southern and central Sweden and along the coast of northern Sweden, in areas characterized by frequent ley production (Eriksson et al. 1997). However, it might not be reasonable to increase the limit value to more than $2.2 \% \mathrm{C}_{\mathrm{o}}$ for other reasons, and then a changed $\mathrm{C}_{\mathrm{o}}$ limit would not change the classification of the Bjärröd soil. Greve et al. (2000) propose the acknowledgement of hortic as a second level qualifier in all WRB groups and the reintroduction of an upper P-limit of 100 ppm $\mathrm{NaHCO}_{3}$ extractable $\mathrm{P}_{2} \mathrm{O}_{5}\left(=44 \mathrm{mg} \mathrm{P} \mathrm{kg}^{-1}\right)$ for mollic horizons in order to allow many of the agricultural 
Slånberg, L. \& Hylander, L.D. Classification of three Swedish soils

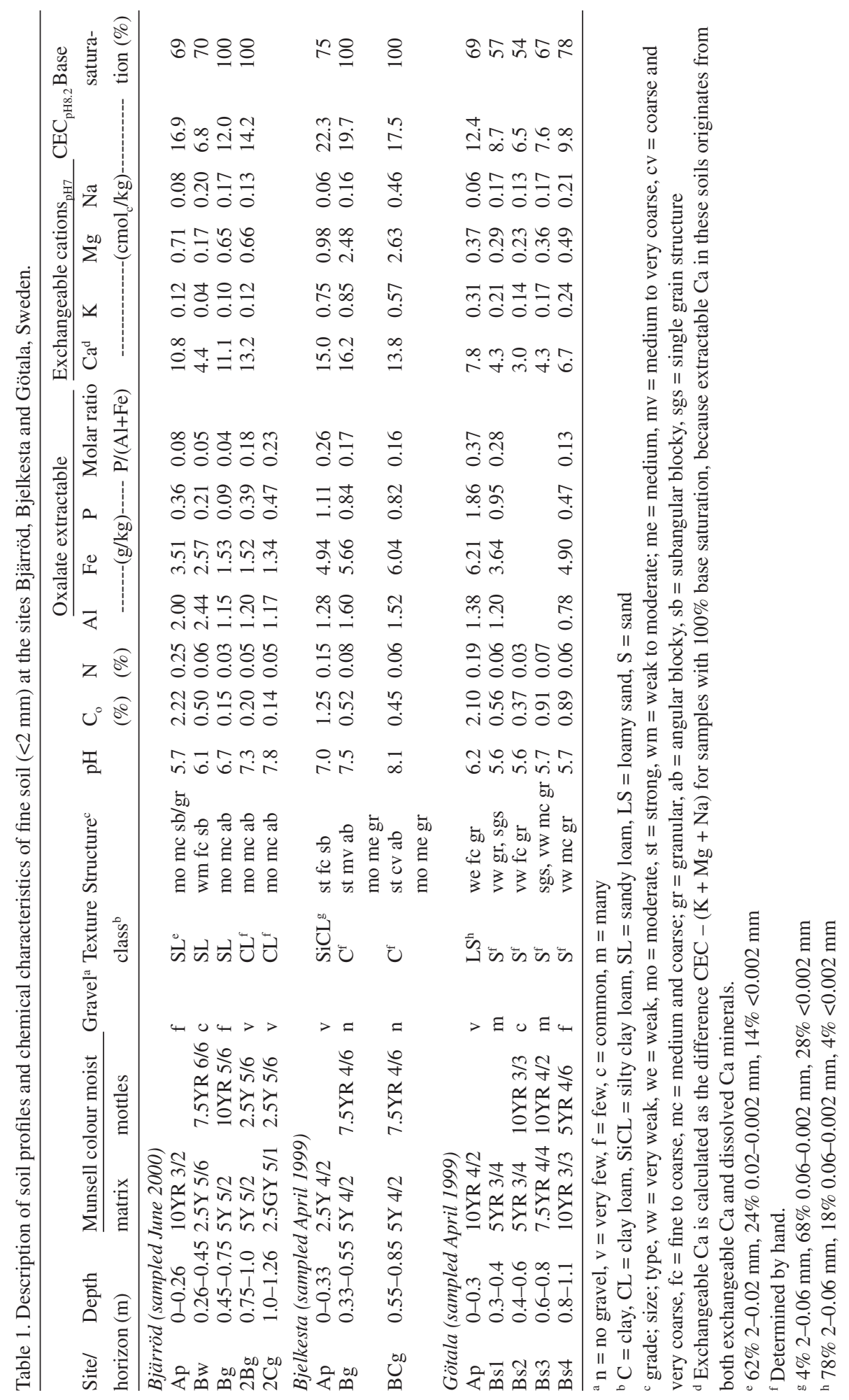


Vol. 13 (2004): 378-389.

soils to have hortic A-horizons. However, not even this would change the classification of the Bjärröd soil, because the low $\mathrm{P}$ content is excluding the soil from having a hortic horizon. Olsen-P (Olsen and Sommers 1982) was only $5.3 \mathrm{mg} \mathrm{P} \mathrm{kg}^{-1}$ (Börling, K. personal communication). This low $\mathrm{P}$ content is very rare in Swedish agricultural soils, only encountered in soils cultivated without $\mathrm{P}$ fertilization for several decades (Börling et al. 2001), and common fertilization practice would soon raise the P-level. A Danish spot test revealed that about two thirds of the Danish agricultural soils contain > $250 \mathrm{mg}$ citric acid extractable $\mathrm{P}_{2} \mathrm{O}_{5} \mathrm{~kg}^{-1}$ soil in the plough layer (Breuning-Madsen and Jensen 1996). The situation is probably similar in areas with intensive agriculture in Sweden. Eriksson et al. (1997) found that out of 3000 Swedish arable soils, only $14 \%$ were in the two lowest P-AL classes, and $50 \%$, in southern Sweden almost all, were in the two highest classes. Many of these soils would probably fulfil the $\mathrm{P}$ criterion for a hortic horizon. Probably, many of the soils classified as Phaeozems according to WRB also contain enough $\mathrm{P}$ to meet the criteria for a hortic horizon, but Bjärröd, obviously, does not. Even if the soil is not representative in its very low $\mathrm{P}$ content, the Bjärröd soil can be used as a proof that WRB mollic horizons, also if taking the changes proposed above into account, can be formed in extensive farmland in south Swedish climate.

We recognize four drawbacks by focusing on the P status and using the hortic horizon to exclude the Nordic soils with man-made mollic horizons from being classified as Phaeozems as Greve et al. (2000) proposed. Firstly, the P content is a characteristic quite easily changed by short-term human influence, i.e. $\mathrm{P}$ addition will raise the $\mathrm{P}$-level enough to fulfil the $\mathrm{P}$ criteria on most soils, while omitting P fertilization would lead to a decrease in a comparably close future. Secondly, the focus on $\mathrm{P}$ status will result in a distinction at highest classification level between similar soils with different $\mathrm{P}$ conditions. Less fertilized soils, as the Bjärröd soil, will be classified as Phaeozems and soils with a high $\mathrm{P}$ fertilizer input as something else, e.g. hortic Cambisol. Thirdly, the use of the hortic horizon for common agricultural topsoils makes it impos- sible to distinguish soils with a larger accumulation of organic matter, unless introducing another horizon. Fourthly, classification according to P status requires an additional chemical analysis.

Krogh and Greve (1999) propose the introduction of an anthric horizon meeting all the criteria of mollic or umbric horizons and also showing evidence of disturbance by human activities by one or more properties. The anthric horizon shall not qualify for a Phaeozem if e.g. its lower boundary is coinciding with the ploughing depth. For Bjärröd, the sharp lower boundary would be enough to classify an anthric horizon. We would prefer the name agric instead of anthric, because it associates better with the classification criteria, which are more related to agriculture specifically than to human activities in general. The full classification of the Bjärröd soil according to the Krogh and Greve proposal to WRB but with Anthric changed to Agric would be: Agric Endogleyic Cambisol (Ruptic). Corresponding classification with Soil Taxonomy would be: coarse loamy, mesic Agric Oxiaquic Eutrudept. We think that these classifications summarize the most important characters of the Bjärröd soil in a better way than the present classification systems. The low fertility is not recognized, but fertilizing and liming could easily change that. The proposal of Krogh and Greve (1999) are focusing on features verifying that the soil would not have a mollic horizon or be a Phaeozem without agricultural influence. In this and probably many other Nordic soils, the depth criteria of a mollic horizon would not have been met without the deep mixing of the soil by farming practices.

\section{Bjelkesta profile}

The plough layer at Bjelkesta is classified as an ochric A-horizon/epipedon, because the colour is a little too light to fulfil the criteria of a mollic horizon. The soil has reductomorphic properties within $50 \mathrm{~cm}$ from the surface, indicated by the olive grey matrix, not changing upon air-exposure, and strong brown colour along cracks and root channels (Table 1). The B-horizon is classified as cambic with Gleyic properties/Aquic conditions due to the colours, $\mathrm{C}$ content and distribution, and the soil struc- 
ture. The base saturation is $100 \%$ from $0.33 \mathrm{~m}$ down to the groundwater level at $0.85 \mathrm{~m}$ and we assume it to be the same for at least another $15 \mathrm{~cm}$ downwards. The Ap has a $75 \%$ base saturation, which is not enough to classify the soil as Hypereutric. Instead the soil is an Orthieutric Gleysol according to WRB. According to Soil Taxonomy, it is a fine, frigid Typic Endoaquept. The classification seems useful except for that the valuable information about the characteristically high fertility due to the high base saturation is not recognized in the Soil Taxonomy. Our proposal is to add a Eutric subgroup to the Endoaquepts, which would result in a classification of the Bjelkesta soil as a fine, frigid Eutric Endoaquept. The characteristic of deep cracks being formed at dry conditions is not considered in either of the systems as no vertic horizon can be classified. The risk of losses of particulate $\mathrm{P}$ through preferential flow in macropores has been found to be large in clayey soils (Skaggs et al. 1994, Djodjic et al. 1999). Most soil particles found in the drainage water originate from the plough layer (Øygarden et al. 1997, Djodjic et al. 1999), so in soils such as this, with high $P$ content in Ap, the losses can be considerable. We think that it would be useful if a soil's ability to form cracks could be included in the name as a lower level unit.

\section{Götala profile}

The topsoil is classified as an ochric A-horizon/ epipedon. No other diagnostic horizons could be found using a strict application of WRB or Soil Taxonomy. Hence, according to WRB the soil is classified as a Haplic Arenosol, and according to Soil Taxonomy: frigid Typic Udipsamment. The criteria of soil colour, $\mathrm{pH} \leq 5.9$ and $\mathrm{C}_{\mathrm{o}} \geq 0.6 \%$ for spodic horizons were met in the Bs1 $(0.3-0.4 \mathrm{~m})$ and $\mathrm{Bs} 3(0.6-0.8 \mathrm{~m}$ ) layers (Table 1$)$. The $\mathrm{C}_{\mathrm{o}}$ content was too low in the $0.4-0.6 \mathrm{~m}$ layer, and below $0.8 \mathrm{~m}$, the colour criteria for a spodic horizon were not met. The $\mathrm{pH}$ was 5.9 or lower in all B-horizons and, hence, fulfilling the criterion of the spodic horizon but with no margin. The $\mathrm{pH}$-criterion was proposed by Greve et al. (2000) to be left out in agricultural soils because liming can easily change $\mathrm{pH}$, and we think it would be appropriate. If there had been an E-horizon above Bs1, it would have been enough to classify it as a spodic horizon according to Soil Taxonomy. If the albic horizon is missing, as in this soil where it has probably been mixed into Ap by tilling practices, further characteristics are needed to fulfil the criteria of a spodic horizon. This soil does not contain enough oxalate extractable $\mathrm{Al}$ and $\mathrm{Fe}$ for a spodic horizon anywhere in the profile, and it contains even more oxalate extractable $\mathrm{Al}$ and $\mathrm{Fe}$ in $\mathrm{Ap}$ than in the $\mathrm{B}$ horizon (Table 1). It does not fulfil any of the alternative criteria in Soil Taxonomy either and, hence, is no Podzol/Spodosol even if accepting the changes proposed by Greve et al. (2000). An albic horizon is a good indicator of eluviation/illuviation processes, but the use of different criteria in Soil Taxonomy for soils with or without an albic horizon do in practice mean that a further developed podzolization is required for cultivated soils, where the albic horizon has been mixed into Ap, compared to corresponding undisturbed soils, to recognize a horizon as spodic. The Götala soil would probably develop an albic horizon with time if left to nature. Thereby, a spodic horizon would be defined according to Soil Taxonomy, and also according to the WRB with the changes proposed by Greve et al. (2000). We find it correct that the Götala soil cannot be classified as a Podzol, mainly because the content of oxalate extractable $\mathrm{Al}$ and $\mathrm{Fe}$ is not high enough, but it is unfortunate that "close to spodic" horizons such as this cannot be recognized with the present classification systems. In the Soil Taxonomy key of Udipsamments, there is a possibility to key out a Spodic Udipsamment with lower requirements of podzolization, with ammonium oxalate extractable $\mathrm{Al}+1 / 2 \mathrm{Fe} \geq 0.25 \%$, expressed on weight basis. The Götala B-horizons are fulfilling this criterion, but the requirement of half that amount or less in the overlying horizon is not fulfilled as the albic horizon is missing.

We propose that the Soil Taxonomy requirement for Spodic Udipsamments of half the amount of ammonium oxalate extractable $\mathrm{Al}+1 / 2 \mathrm{Fe}$ and the corresponding optical density of the oxalate extract (ODOE) value in the overlying horizon is omitted if the overlaying horizon is an Ap that is mixed by tilling practices, and if the colour and $\mathrm{C}_{\mathrm{o}}$ 
Vol. 13 (2004): 378-389.

criteria of a spodic horizon are met. We also propose the introduction of spodic as a lower level unit for the Arenosols of WRB, with lower requirements as related above. Taking these changes into account, the new revised WRB classification of Götala would be: Spodic Arenosol, and revised Soil Taxonomy: frigid Spodic Udipsamment. We think that this classification would improve the understanding of the character of this soil compared to the existing systems. Knowledge about the rather high content of amorphous $\mathrm{Al}$ and $\mathrm{Fe}$ (in combination with the $\mathrm{P}$ status of the soil) is valuable when assessing the risk of $P$ leakage, which otherwise can be high in a coarse textured soil such as this.

When $\mathrm{P}_{\mathrm{ox}}, \mathrm{Fe}_{\mathrm{ox}}$ and $\mathrm{Al}_{\mathrm{ox}}$ are expressed in mol per $\mathrm{kg}$ of soil, the ratio $\mathrm{P}_{\mathrm{ox}} / \alpha\left(\mathrm{Al}_{\mathrm{ox}}+\mathrm{Fe}_{\mathrm{ox}}\right)$ will indicate the degree of $\mathrm{P}$ saturation. A $\alpha$-value of 0.5 was found accurate for acid, sandy soils in central Europe, but may vary depending on soil and laboratory method used (Campillo et al. 1999). Young and less weathered soils in the Nordic countries often contain Ca-phosphates (Peltovuori et al. 2002), which are dissolved by the oxalate extract, and thereby the quantity of $\mathrm{P}$ sorbed to amorphous $\mathrm{Al}$ and $\mathrm{Fe}$ oxy-hydroxides is overestimated in these soils. However, the Götala soil is an acid and sandy soil, and Borggaard et al. (1990) found the value 0.5 to overestimate the $\mathrm{P}$ adsorption capacity when applied on some acid, sandy soils in Denmark. Breeuwsma and Silva (1992) assessed a P saturation of $25 \%$ as the critical limit in Dutch soils, above which $\mathrm{P}$ contents $\geq 0.1 \mathrm{mg} \mathrm{P}^{-1}$ in the leachate often were encountered. This value is considered a critical level for the water quality in the Netherlands. Using $\alpha=0.5$ estimates the P saturation to $74 \%$ in Ap and $56 \%$ in upper B at Götala, which is well above the $25 \%$-limit and a very high degree of saturation. This is a consequence of high input of farmyard manure. High content of $\mathrm{P}$ in $0.01 \mathrm{M} \mathrm{CaCl} \mathrm{Ca}_{2}$ extracts of the soil (Slånberg, unpublished data) also confirms that this soil is at high risk of leaking $\mathrm{P}$. The $\mathrm{P}$ saturation of Götala Ap is high in comparison with the values of $24-38 \%$ found in a screening of Danish soils (Rubæk et al. 2000), where the highest values were found in sandy soils. The P saturation of the
Götala Bs1 $(0.3-0.4 \mathrm{~m})$ was higher than the 22$26 \%$ that was found in the $0.25-0.50 \mathrm{~m}$ layers of the Danish study, probably partly due to the shallower sampling depth at Götala, but anyhow remarkable.

\section{Conclusions}

Soil classification according to the present systems is misleading for certain soils such as man-made Phaeozems/Mollisols, in this study exemplified by the Bjärröd soil. We also encountered problems with relevant information being omitted in the classifications of Bjelkesta, where the characteristically high base saturation was not recognized in Soil Taxonomy, and of Götala, where the obvious spodic character, not enough developed to fulfil the criteria of a spodic horizon, was left out in the names in both classification systems. On basis of the three Swedish arable soils we classified, we propose the following changes to be applied in both WRB and Soil Taxonomy:

- We agree with Kirchmann et al. (1999) that the $\mathrm{C}_{\mathrm{o}}$-limit for a mollic horizon should be increased considerably to better agree with the general description of a "moderate to high content of organic matter" (FAO 1998). From a Swedish point of view, a limit of $3.5 \% \mathrm{C}_{\mathrm{o}}$ would be suitable. Maybe this would only be suitable for soils formed in a cool climate.

- We support the proposal of Krogh and Greve (1999) of the introduction of an Anthric horizon and the criteria for this; meeting all the requirements for a mollic or umbric horizon and also showing evidence of human disturbance by e.g. a sharp lower boundary. The Anthric horizon shall not qualify for a Phaeozem. We would prefer the name Agric instead of Anthric. We think this can also be applied to Soil Taxonomy.

- Omission of the requirement for a spodic horizon to have a content of half the $\mathrm{Al}_{\mathrm{ox}}+1 / 2 \mathrm{Fe}_{\text {ox }}$ and corresponding ODOE-values in the overlying horizon, when this is an Ap that is mixed by tilling practices. 
Slånberg, L. \& Hylander, L.D. Classification of three Swedish soils

- Introduction of spodic as a lower level unit for the Arenosols of WRB with lower criteria as in Soil Taxonomy with $\mathrm{Al}_{\text {ox }}+1 / 2 \mathrm{Fe}_{\text {ox }} \geq 0.25 \%$ and, in both WRB and Soil Taxonomy, with no requirement of half that amount in the overlying horizon when this is an Ap as above.

- Addition of a eutric subgroup to the Endoaquepts in Soil Taxonomy.

Adopting these changes to the WRB and Soil Taxonomy would increase the credibility of the international classification systems for Swedish soils and make them more useful as land assessment tools.

Intensified soil classification worldwide according to WRB and Soil Taxonomy renders comparisons and evaluations possible on a global scale. However, the largest benefits of uniform classification criteria may be obtained by policy makers at a regional level such as the EU, where social planning and environmental management could be based on characteristics and distribution of different soils. For example by reserving good agricultural soils from exploitation and by adapting P fertilization to actual soils in order to reduce $\mathrm{P}$ leaching and eutrophication of surface waters.

Acknowledgements. Special thanks to Olle Selinus, Geological Survey of Sweden, and Sven Gesslein, Malmöhus läns hushållningssällskap, for providing geological and meteorological information and to Jan Eriksson and Ingmar Messing, Swedish University of Agricultural Sciences, for valuable discussions.

\section{References}

Alexandersson, H., Karlström, C. \& Larsson-McCann, S. 1991. Temperature and precipitation in Sweden 19611990. Reference normals. Meteorologi $\mathrm{nr}$ 81. The Swedish Meteorological and Hydrological Institute. Norrköping, Sweden. 88 p. (in Swedish, English summary).

Borggaard, O.K., Jørgensen, S.S., Møberg, J.P. \& RabenLange, B. 1990. Influence of organic matter on phosphate adsorption by aluminium and iron oxides in sandy soils. Journal of Soil Science 41: 443-449.

Börling, K., Otabbong, E. \& Barberis, E. 2001. Phosphorus sorption in relation to soil properties in some cultivated
Swedish soils. Nutrient Cycling in Agroecosystems 59, 1: 39-46.

Breeuwsma, A. \& Silva, S. 1992. Phosphorus fertilisation and environmental effects in The Netherlands and the Po region (Italy). Agricultural Research Department Report 57. The Winand Staring Centre for Integrated Land, Soil and Water Research. Wageningen. The Netherlands. $39 \mathrm{p}$.

Breuning-Madsen, H. \& Jensen, N.H. 1996. Soil map of Denmark according to the revised FAO legend 1990. Danish Journal of Geography 96: 51-59.

Buurman, P., Lagen, B. van \& Velthorst, E.J. (eds.). 1996. Manual for soil and water analysis. Backhuys Publ., Leiden, The Netherlands. $314 \mathrm{p}$.

Campillo, M.C. del, Zee, S.E.A.T.M. van der \& Torrent, J. 1999. Modelling long-term phosphorus leaching and changes in phosphorus fertility in excessively fertilized acid sandy soils. European Journal of Soil Science 50, 3: 391-399.

Clason, Å. \& Granström, B. (eds.). 1992. National atlas of Sweden. Agriculture. SNA, Stockholm. Sweden. 128 p.

Commission of the European Communities 2002. Towards a thematic strategy for soil protection. Communication from the Commission to the Council, the European Parliament, the Economic and Social Committee and the Committee of the Regions. COM (2002) 179. 35 p.

Djodjic, F., Bergström, L., Uhlén, B. \& Shirmohammadi, A. 1999. Mode of transport of surface-applied phosporus33 through a clay and sandy soil. Journal of Environmental Quality 28: 1273-1282.

Egnér, H., Riehm, H. \& Domingo, W.R. 1960. Untersuchungen über die chemische Bodenanalyse als Grundlage für die Beurteilung des Nährstoffzustandes der Böden. II. Chemische Extraktionsmethoden zur Phosphor- und Kaliumbestimmung. Kungliga Lantbrukshögskolans Annaler 26: 199-215. (in German).

Ekström, G. 1953. Åkermarkens matjordstyper. I: Atlas över Sverige, nr 63-64. Svenska Sällskapet för antropologi och geografi. Stockholm. Sweden. (in Swedish).

Eriksson, J., Andersson, A. \& Andersson, R. 1997. Current status of Swedish arable soils. Swedish Environmental Protection Agency. Report 4778. Stockholm, Sweden. $114 \mathrm{p}$.

FAO 1990. Guidelines for soil description. Soil Resources, Management and Conservation Service, Land and Water Development Division, FAO, Rome, Italy. 119 p.

FAO 1998. World Reference Base for Soil Resources. World Soil Resources Report 84. FAO, Rome, Italy. 81 p. + app.

Fredén, C. (ed.). 1995. National atlas of Sweden. Geology. SNA, Stockholm, Sweden. p. 14-75.

Gesslein, S. 1995. Biologisk aktivitet och olika växtnäringsämnen i markprofilen från 6 olika odlingssystem på Bjärröd. Andra växtföljdsomloppet. Projekt SV 143. Malmöhus läns hushållningssällskap, Malmö, Sweden. 27 p. + app. 31 p. (in Swedish).

Greve, M.H., Yli-Halla, M., Nyborg, A.A. \& Öborn, I. 2000. Appraisal of World Reference Base for Soil Resources - from a Nordic point of view. Danish Journal of Geography 100: 15-26. 
Vol. 13 (2004): 378-389.

Kirchmann, H. \& Eriksson, J. 1993. Properties and classification of soils of the Swedish long-term fertility experiments. Sites at Örja and Orup. Acta Agriculturae Scandinavica Section B 43: 193-205.

Kirchmann, H., Eriksson, J. \& Snäll, S. 1999. Properties and classification of soils of the Swedish long-term fertility experiments. Sites at Ekebo and Fjärdingslöv. Acta Agriculturae Scandinavica Section B 49: 25-38.

Kirchmann, H., Snäll, S. \& Eriksson, J. 1996. Properties and classification of soils of the Swedish long-term fertility experiments. Sites at Västraby and S. Ugglarp. Acta Agriculturae Scandinavica Section B 46: 86-97.

Krogh, L. \& Greve, M.H. 1999. Evaluation of World Reference Base for Soil Resources and FAO Soil Map of the World using nationwide grid soil data from Denmark. Soil Use and Management 15: 157-166.

LECO 1994. CNS-2000 elemental analyzer instruction manual. Version 4.0. LECO Corporation, Chicago, USA. 292 p.

Ljung, G. 1987. Mekanisk analys. Beskrivning av en rationell metod för jordartsanalys. Swedish Univ. Agric. Sci., Dept. of Soil Sciences. Div. of Agricultural Hydrotechnics. 87: 2. Uppsala, Sweden. 13 p. (in Swedish).

Munsell soil color charts 1975. Macbeth, Baltimore, Maryland, USA.

Olsen, S.R. \& Sommers, L.E. 1982. Phosphorus. In: Page, A.L. (ed.). Methods of soil analysis, part 2. Chemical and microbiological properties. 2nd ed. Agronomy Monographs 9. ASA and SSSA, Madison, WI, USA. p. 403-430.

Øygarden, L., Kværner, J. \& Jenssen, P.D. 1997. Soil erosion via preferential flow to drainage systems in clay soils. Geoderma 76: 65-86.

Peltovuori, T., Uusitalo, R. \& Kauppila, T. 2002. Phosphorus reserves and apparent phosphorus saturation in four weakly developed cultivated pedons. Geoderma 110: 35-47.

Perkin Elmer 1993. ICP-OES Perkin Elmer Optima 3000 DV hardware guide. The Perkin Elmer Corporation, Norwalk, CT, USA. 245 p.

Raab, B. \& Vedin, H. (eds.). 1995. National atlas of Swe- den. Climate, lakes and rivers. SNA, Stockholm, Sweden. $176 \mathrm{p}$.

Rubæk, G.H., Djuurhuus, J., Heckrath, G., Olesen, S.E. \& Østergaard, H.S. 2000. Are Danish soils saturated with phosphorous? DJF rapport, Markbrug 34: 17-30. (in Danish with English summary).

Skaggs, R.W., Brevé, M.A. \& Gilliam, J.W. 1994. Hydrologic and water quality impacts of agricultural drainage. Critical Reviews in Environmental Science and Technology 24: 1-32.

Soil Survey Staff 1974. Soil Taxonomy. A basic system of soil classification for making and interpreting soil surveys. Agriculture Handbook No. 463. Soil Conservation Service, U.S. Department of Agriculture. Washington, DC, USA.

Soil Survey Staff 1998. Keys to soil taxonomy. 8th ed. U.S. Department of Agriculture, Natural Resources Conservation Service. Washington, DC, USA. 327 p.

Swedish University of Agricultural Sciences 1999. Växtnäringsförsök 1998. Skörderesultat med växt- och jordanalyser. Swedish University of Agricultural Sciences, Dept. of Soil Sci., Div. of Soil Fertility. Rapport Special nr. 9. Uppsala, Sweden. 262 p. (in Swedish).

Tiberg, E. (ed.). 1998. Nordic Reference Soils. 1. Characterization and classification of 13 typical Nordic soils. TemaNord 537.

United States Salinity Laboratory Staff 1954. Exchangeable cations. In: Diagnosis and improvement of saline and alkali soils. Agriculture Handbook No. 60. United States Department of Agriculture, Riverside, California. p. 100-101.

USDA, Soil Conservation Service 1981. Soil Taxonomy. A basic System of Soil Classification and Interpreting Soil Surveys. Castle House Publ. Kent, Great Britain.

Weibull, C.G. 1923. Skånska jordbrukets historia intill 1800talets början. Skrifter utgivna av Skånska Hushållningssällskapet vid dess 100-årsjubileum 1917. Lund, Sweden. 239 p. (in Swedish).

Yli-Halla, M. \& Mokma, D.L. 1999. Classification of soils of Finland according to Soil Taxonomy. Soil Survey Horizons 40: 59-69. 